\title{
COMPARISON STUDY OF EXPERIMENTAL AND SIMULATION TEMPERATURE DATA IN THE ESTERIFICATION PROCESS OF PALM FATTY ACID DISTILLATE (PFAD) IN A FLUIDISED REACTOR
}

\author{
(Date received:9.6.2010/Date accepted:30.7.2011) \\ Abd Rahman, N. ${ }^{1}$, Sam, Yet $^{2}$ and Noorhisham, T.K. ${ }^{3}$ \\ ${ }^{1,2,3}$ Department of Chemical Engineering and Process \\ Faculty of Engineering, Universiti Kebangsaan Malaysia \\ 43650, Bangi, Selangor \\ Email:liza@eng.ukm.my
}

\begin{abstract}
Palm Oil Fatty Acid Distillate (PFAD) is a by-product from palm oil refinery process and normally used as ingredient of making candles, soap and others. Recently, many researchers have been carried out to diversify the utilisation of PFAD in industry. Among others is the enzimatically production of sugar ester using PFAD as substrate. However, limited kinetic and simulation data hindered the effort of large scale production. Hence, this study was executed to determine the kinetic parameters of the esterification process based on the simplified Ping-pong Bi-Bi model under the temperature range of $30^{\circ} \mathrm{C} \sim 45^{\circ} \mathrm{C}$ where immobilised lipase (Lipozyme 1M) was used as biocatalyst and isopropyl alcohol was used as solvent. The reaction was conducted in a cylinder resemble a fluidised reactor. Kinetic parameters derived from the experiments were used to simulate the production of sugar ester. The optimum temperature for the production of sugar ester was found to be at $40^{\circ} \mathrm{C}$. The experimental results deviate slightly from the simulation results with error percentage of less than $11 \%$. The model can be used to predict the production of sugar ester when the concentrations of the reactants are varied.
\end{abstract}

Keywords: Esterification Process, Fluidised Bed Reactor, Immobilised Lipase, Isopropyl, PFAD, Ping-pong Bi-Bi Model

\subsection{INTRODUCTION}

Sugar ester is a versatile product that can be used as surfactant in food, detergent and cosmetic industries [1, 2, 3]. Unfortunately, production of this ester is rather limited to chemical processes which normally requiring high temperature and the use of toxic organic solvent. Another way of producing ester is by esterification process using enzymatic reaction (involving lipase) which generally regarded as safe and environmentally friendly as well as is more products specific. It is regarded as key step to produce pure sugar ester due to its stereoselective acelyation characters of the enzyme [4]. Lipase is an enzyme that is able to catalysing reversible reaction of disengagement of carboxyl ester bonding for monoester, diester and triester [5]. With the immobilisation, the usage of lipase can be increased since it can be used repetitively up to 10 - 15 times in a batch process and more than 50 times in continuous process [6].

Fluidised bed reactor had been commercially used since 1920's for example as for coal gasification to produce monoxide and hydrogen gases [7]. One of the advantages of fluidised bed reactor is the possibility of continuous operation allowing reactants and catalyst being fed continuously and without mechanical agitation as well as easy control of temperature making it attractive for the operation using immobilised enzyme which normally has a fragile and delicate structure.
Uniform temperature is achieved in the reactor resulted of the turbulent flow and larger interfacial area between fluid and small particle [7]. Because of these advantages, fluidised bed reactor was commonly used in research and industry.

For biochemical catalyst reaction by enzymes, temperature is an important parameter due to the fact that high temperature can denature the enzyme while low temperature might slow its activities. For maximum reaction to occcur, optimum temperature is much sought. In this initial study, the esterification of PFAD using immobilised lipase (Lipozyme IM) was executed in fluidised reactor at different temperature to obtain the data to be compared with simulation data using MATLAB (version 6.1).

\subsection{MATERIALS AND METHODS}

\subsection{Materials}

(a) PFAD is kindly donated by Dr Mah from Malaysian Palm Oil Board (MPOB). Though it is solidified at room temperature, PFAD was stored at $4^{\circ} \mathrm{C}$.

(b) Fructose is obtained from R\&M Chemical, UK.

(c) Tert-butyl alcohol

(d) Immobilised lipase (Lipozyme IM) is purchased from NovoNordisk (Denmark) and originated from Mucor meihei immobilised to anion exchange resin with activity of 5-6 acidolysis unit per gram. 
(e) Fluidised reactor as shown in Figure 1, used was a cylinder column with $30 \mathrm{~cm}$ (4) in height and $3 \mathrm{~cm}$ in diameter supported by retort stand (6). Rubber stopper (7) was placed at the top and a tube (2) ( $4 \mathrm{~mm}$ diameter) was inserted into the cylinder column where air was pumped (1) via this duct using a flowmeter to control the flowrate. To control the temperature, the reactor was placed in a circulator water bath (3) (Protech Electronic) ensuring reactants level was lower than water level as well as being covered throughout the experiment preventing and minimising heat lost to surrounding. Samples $(12.5 \mathrm{ml})$ were taken at certain time interval (5).

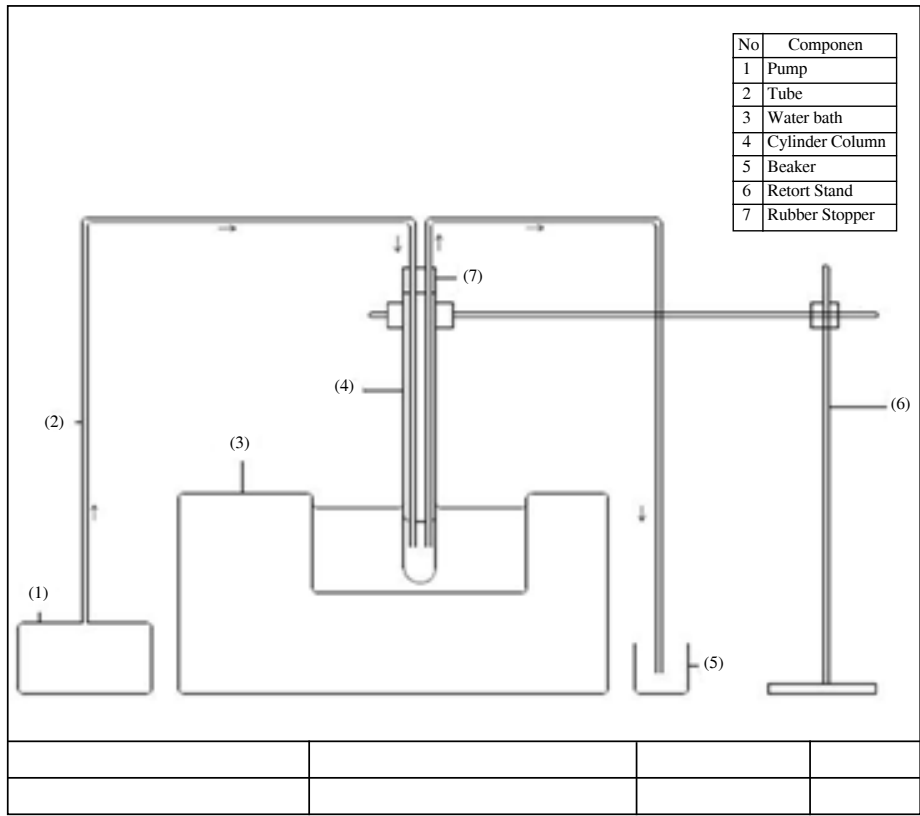

Figure 1: Schematic diagram of fluidised reactor

\subsection{Materials}

\subsubsection{Reaction}

Fructose $(4.32 \mathrm{~g})$ with PFAD at mass ratio of $1 / 10$ was mixed with $150 \mathrm{ml}$ of tert-butyl alcohol and $10 \%$ Lipozyme IM to produce fructose ester. Samples $(12.5 \mathrm{ml})$ were taken at certain time interval $(5,10,12,20,24,28,30$ and 36 hours $)$ and then filtered to separate the immobilised lipase. Alcohol solvent was evaporated using rotavapor at $90^{\circ} \mathrm{C}$ under vacuum pressure. The non-reacted fructose, PFAD and fructose ester were dissolved in the chloroform and stirred overnight. The non-reacted fructose was filtered while the ester was analysed and detected using thin layer chromatography (TLC). Reaction were repeated at different temperatures $\left(30^{\circ} \mathrm{C}, 35^{\circ} \mathrm{C}, 40^{\circ} \mathrm{C}\right.$ and $\left.45^{\circ} \mathrm{C}\right)$ to obtain the optimum temperature.

\subsubsection{Thin Layer Chromatography}

Qualitative estimation for sugar ester was done using thin later chromatography [8]. Samples were diluted in chloroform and filtered before $0.2 \mathrm{ml}$ volume is used. The thin layer plates were carefully placed in a tank containing of solvents, chloroform/ methanol/acetic acid/water (were used as mobile phase) at ratio $80 / 10 / 8 / 2(\mathrm{v} / \mathrm{v} / \mathrm{v} / \mathrm{v})$ for 3 hours. The presence of sugar ester was observed under the UV light.

\subsubsection{Mathematical Model for Simulation}

Mechanism for esterification reaction catalysed by lipase is assumed to follow the Ping-pong Bi-Bi mechanism. Using the King Altman method [9], the formation equation of monoester (M) and diester (D) is given by,

$$
\begin{aligned}
\frac{1 d M}{V d t k_{1}} & =\frac{k_{1} k_{2}[F A][A G]-k_{1} k_{3}[F A][M] E_{T}}{[F A]+k_{2}[G]+k_{3}[M]} \\
\frac{1 d D}{V d t} & =\frac{\left(k_{3} k_{1}[F A][M] E_{T}\right.}{k_{1}[F A]+k_{2}[G]+k_{3}[M]}
\end{aligned}
$$

The mathematical model can be simplified to the MichalisManten equation at low concentration for sugar and monoester [1] With that, the values of $\mathrm{k}_{2}[\mathrm{G}]$ and $\mathrm{k}_{3}[\mathrm{M}]$ can be assumed to be nearly constant and could be altered to $\mathrm{K}_{2}$ and $\mathrm{K}_{3}$, resulted in

$$
\begin{aligned}
\frac{1 d M}{V d t} & =\frac{k_{1}[F A]\left(K_{2}^{\prime}-K_{3}^{\prime}\right) E_{T}}{k_{1}[F A]+K_{2}^{\prime}+K_{3}^{\prime}} \\
\frac{1 d D}{V d t} & =\frac{k_{1}[F A] K_{3}^{\prime} E_{T}}{k_{1}[F A]+K_{2}^{\prime}+K_{3}^{\prime}}
\end{aligned}
$$

When glucose concentrated is limited, the equation become,

$$
-\frac{1}{V} \frac{d M}{d t}=\frac{1}{V} \frac{d D}{d t}=\frac{k_{1}[F A] K_{20} E_{T}}{k_{1}[F A]+K_{20}}
$$

Materials balance for PFAD is given by

$$
[F A]=[\mathrm{Fao}]-[\mathrm{M}]-2[\mathrm{D}]
$$

With the diester concentration is assumed low and can be neglected, the above equation become,

$$
[F A]=[\mathrm{Fao}]-[\mathrm{M}]
$$

For enzyme activity, it is decreasing with time increasing based on the equation below

$$
E_{r}=A_{\mathrm{o}}(1-\alpha) \exp \left(-\mathrm{k}_{\mathrm{da}} \mathrm{t}\right)
$$

$A_{\mathrm{o}}$ is the activity of enzyme and equal to the enzyme initial mass used. This enzyme ratio $(\alpha)$ that being deactivate $\left(k_{d a}\right)$ from time $(t)$ to time.

\subsubsection{Matlab Simulation}

To run the simulation using Matlab version 6.1, few assumptions were made :

(i) Reaction mechanism is following Ping Pong Bi Bi rection as describe in mathematical model in Equation 4.

(ii) Kinetic constants are based on Leaverburk plot.

(iii) Every mole of fructose will produced one mole of ester sugar [10].

(iv) Temperature in the reactor column is assumed equal to the temperature of the water bath.

(v) Heat lost to the surroundings was neglected.

(vi) Enzyme activity is constant during experiment. [11]. 


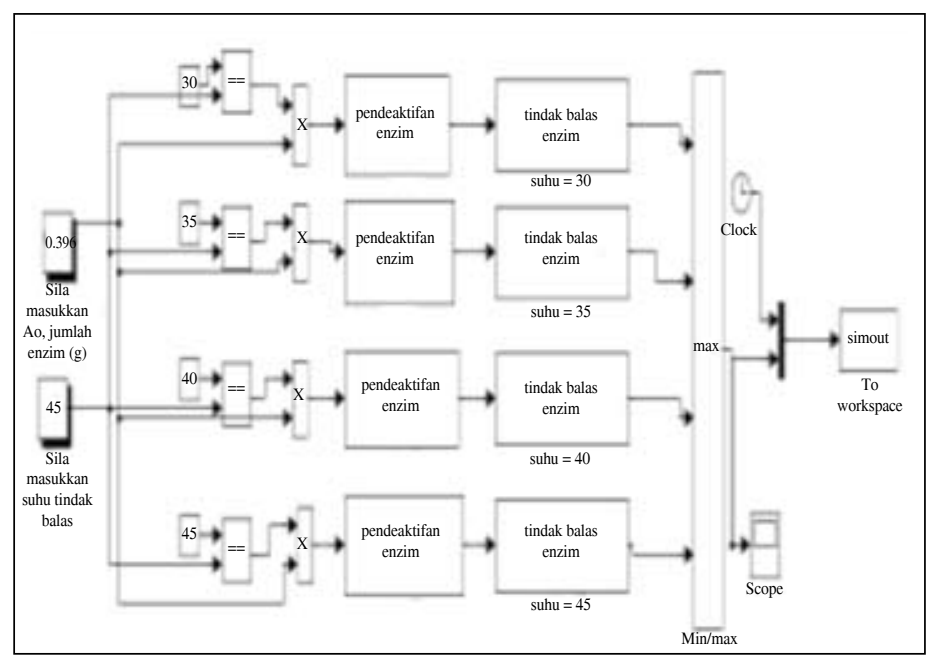

Figure 2: Simulation model for ester production

Figure 2 shows the main simulation model for ester sugar production. "simout" block made the simulation result displayed in the matrix form in the command window. Figures 3 and 4 show the subsystem for enzyme deactivation and enzyme reaction.

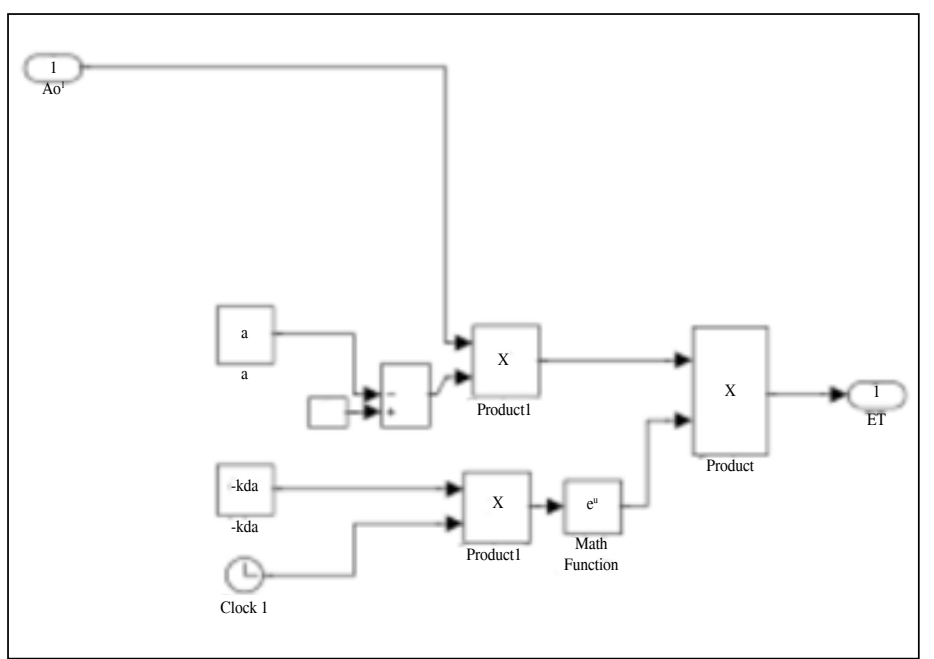

Figure 3: First subsystem model; "Enzyme deactivation"

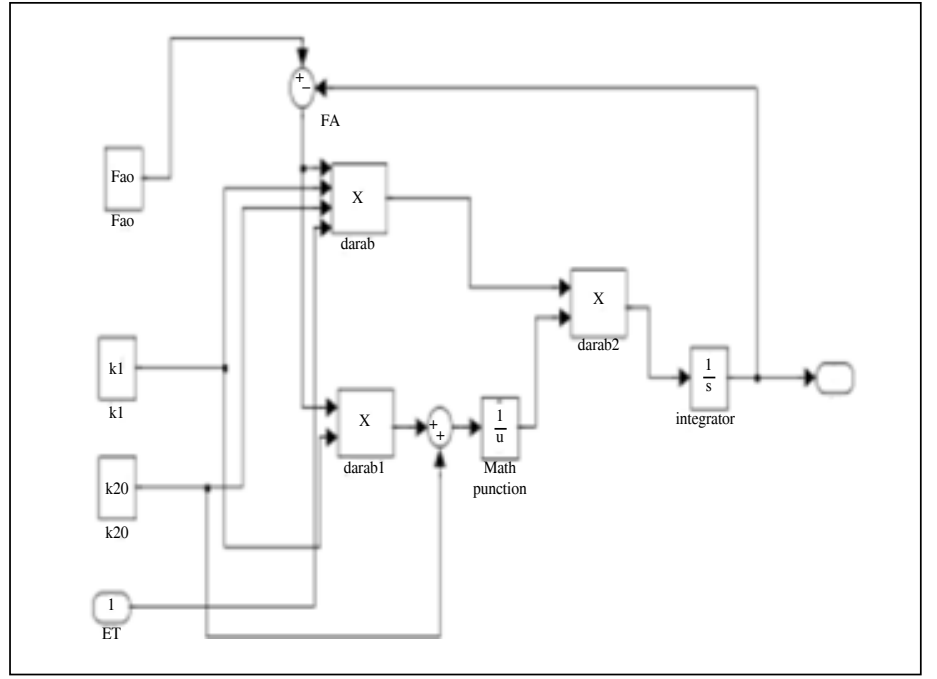

Figure 4: Second subsystem model; "Enzyme reaction"

\subsection{RESULTS AND DISCUSSION}

These sections presenting some results for modelling, experimental and comparison between modelling and experiment.

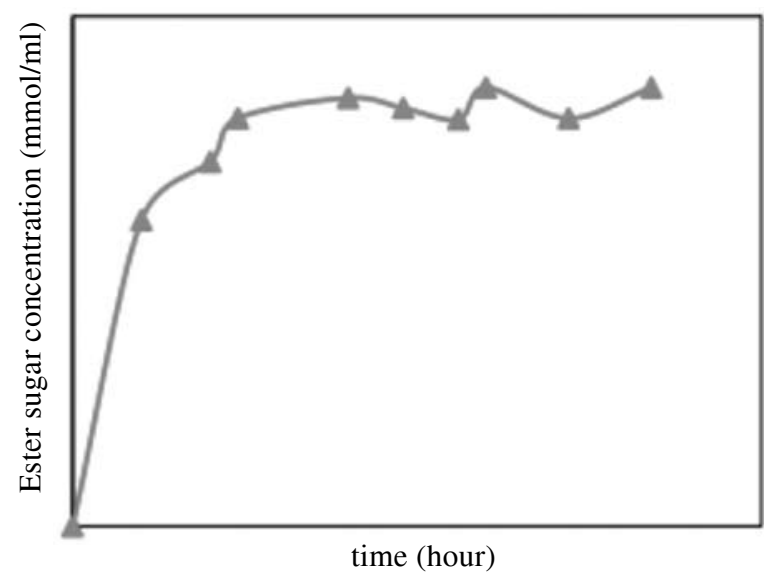

Figure 5: Graph of ester concentration versus time

From this graph, ester formation rate, $r$ [mmol/hour] can be calculated by measure tangent slope at certain point.

From equation (1), a straight line is obtained if ET/r versus $1 /$ FA plotted. $\mathrm{K}_{20}$ is inversed to $\mathrm{y}$ interception while $\mathrm{k}_{1}$ is a graph slope. With this method, kinetic parameter needed for simulation can be calculated.

$$
\begin{aligned}
& -\frac{1}{V} \frac{d M}{d t}=\frac{1}{V} \frac{d D}{d t}=\frac{k_{1}[F A] K_{20} E_{T}}{k_{1}[F A]+K_{20}} \\
& r=\frac{d D}{d t}=\text { ester formation rate } \\
& r=\frac{k_{1}[F A] K_{20} E_{T}}{k_{1}[F A]+K_{20}} \\
& \frac{E_{r}}{r}=\frac{1}{k_{20}}+\frac{1}{k_{1}[F A]}
\end{aligned}
$$

\subsection{Determination of Ester Sugar}

From chromatogram of sugar, TLC, as shown in Figure 6, (Refractive Index, $\mathrm{R}_{\mathrm{f}}=\mathrm{L}_{2} / \mathrm{L}_{0}$ ) value for ester was calculated. Results from chromatogram was analysed under ultra violet light. The results show that sugar ester was found between 0.56 to 0.6 , in agreement with $R_{f}$ value reported by Khaled [8].

$R_{f}$ value for analysed sugar was assumed to be zero while PFAD has the highest $R_{f}$ value 0.85 to 0.9 . This result confirmed that esterification reaction occurred via reaction catalyst by immobilized lipase enzyme. 


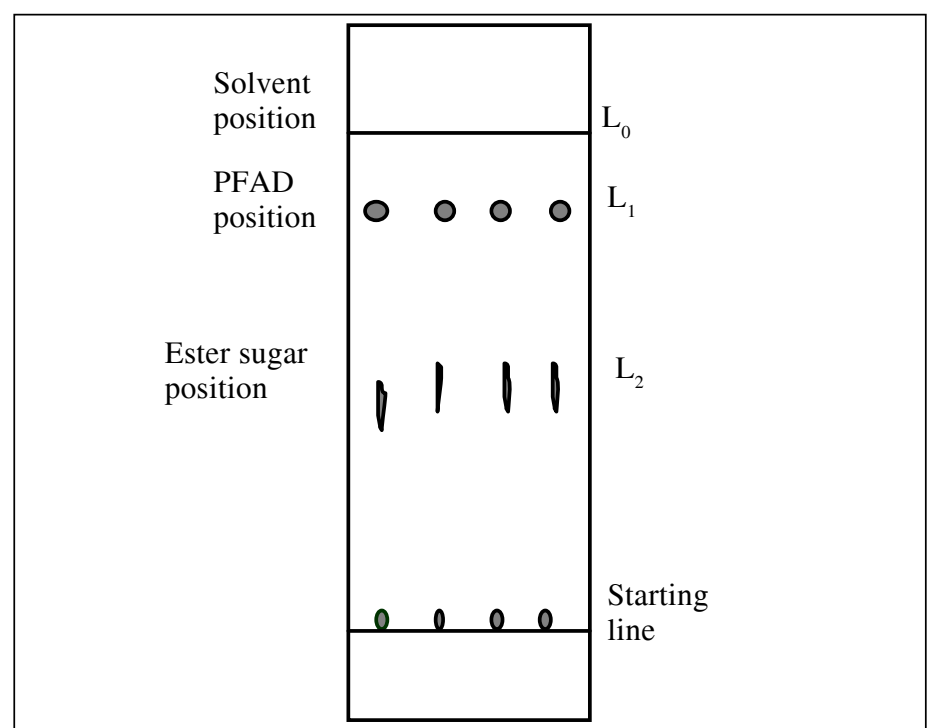

Figure 6: Thin Layer Chromatogram Sketch:

(i) Sample 1, (ii) Sample 2, (iii) Sample 3, (iv) Sample 4

\subsection{The Effect of Temperature to Ester Production}

The effect of temperature was studied by ranging the temperature from $30^{\circ} \mathrm{C}$ to $45^{\circ} \mathrm{C}$. Figure 7 depicted the results of different temperature toward time. From the figure, it shows that after 20 minutes, the reactions become plateau for most temperature under study.

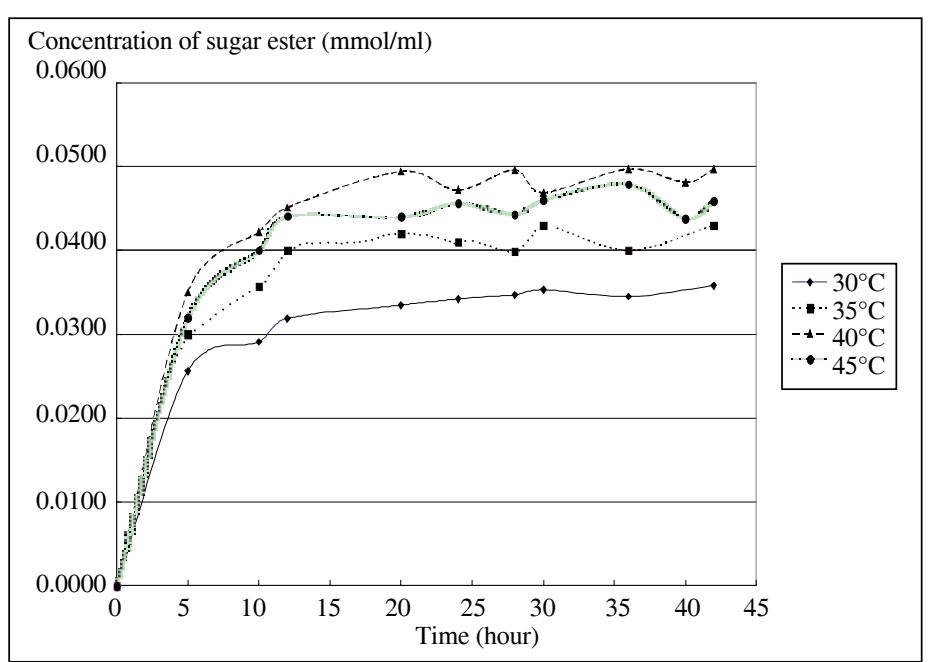

Figure 7: Temperature reaction effect to ester production at different time step with mass $/$ PFAD ratio $=1 / 10$ and lipase concentration $10 \%$

From the ester production profile using different temperature, it is found that when temperature increase from $30^{\circ} \mathrm{C}$, ester production will increase until the temperature reached $40^{\circ} \mathrm{C}$. Hence, ester production decrease when temperature increase to $45^{\circ} \mathrm{C}$ as shown in Figure 6 above. This is due to the fact that lipase enzyme is protein molecules that is sensitive to certain temperature changes. When the temperature increase, lipase enzyme activity will also increase until achieve certain level. From lipase (Lipozyme 1M) production data, temperature ranges between $30-70^{\circ} \mathrm{C}$ was suggested that the active temperature. But optimum temperature for ester production was found to be at $40^{\circ} \mathrm{C}$ but ester acquirement decrease at $50^{\circ} \mathrm{C}$ [2].

\subsection{Determination of Kinetic Parameter from Experimental Result}

From experiment, the kinetic parameters, $\mathrm{k}_{1}$ and $\mathrm{K}_{20}$ were calculated and will be used to run the simulation. Table 1 shows the values of kinetic parameters, $\mathrm{k}_{1}$ and $\mathrm{K}_{20}$ for each temperature under study. Besides that, kinetic parameter as reported in Table 1 is important for design purposes if esterification process was chosen to be commercialised.

Table 1: Calculated kinetic parameter

\begin{tabular}{|c|c|c|}
\hline Temperature & $\mathrm{k}_{1}\left(\right.$ hour $\left.^{-1}\right)$ & $\mathrm{K}_{20}\left(\right.$ hour $\left.^{-1}\right)$ \\
\hline $30^{\circ} \mathrm{C}$ & 0.8900 & 0.023 \\
\hline $35^{\circ} \mathrm{C}$ & 0.9799 & 0.029 \\
\hline $40^{\circ} \mathrm{C}$ & 1.1399 & 0.034 \\
\hline $45^{\circ} \mathrm{C}$ & 1.458 & 0.031 \\
\hline
\end{tabular}

\subsection{Comparison between Experimental and Simulation results}

A comparison study between modified kinetic modelling and experimental was conducted and discussed in this section as shown by Figures 8 to Figure 11 .

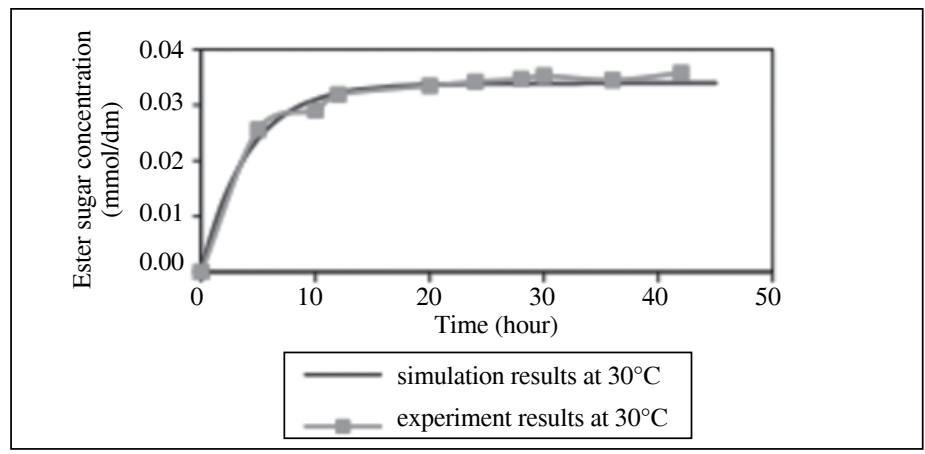

Figure 8: Comparison between simulation and experiment results at $30^{\circ} \mathrm{C}$.

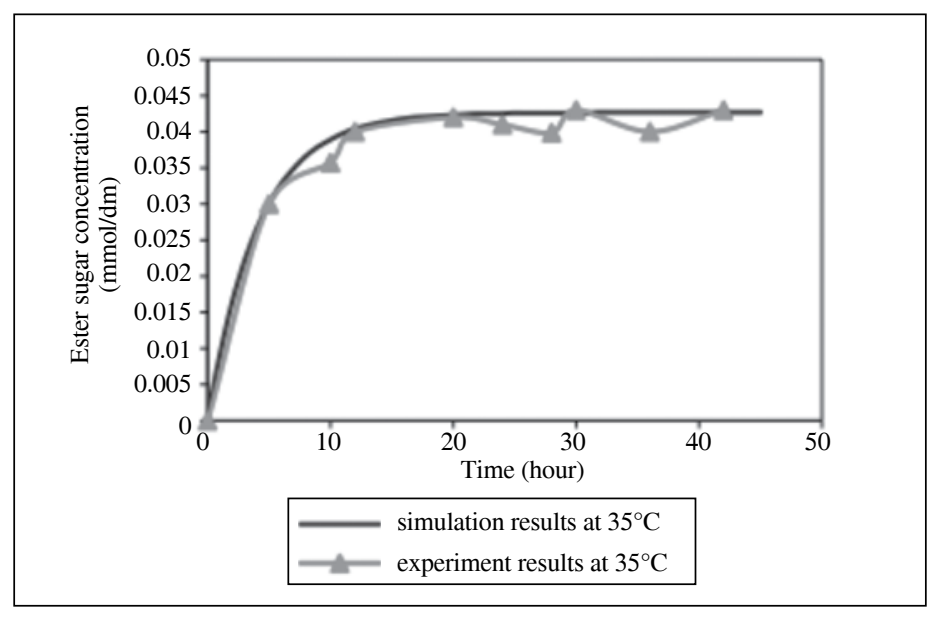

Figure 9: Comparison between simulation and experiment results at $35^{\circ} \mathrm{C}$ 


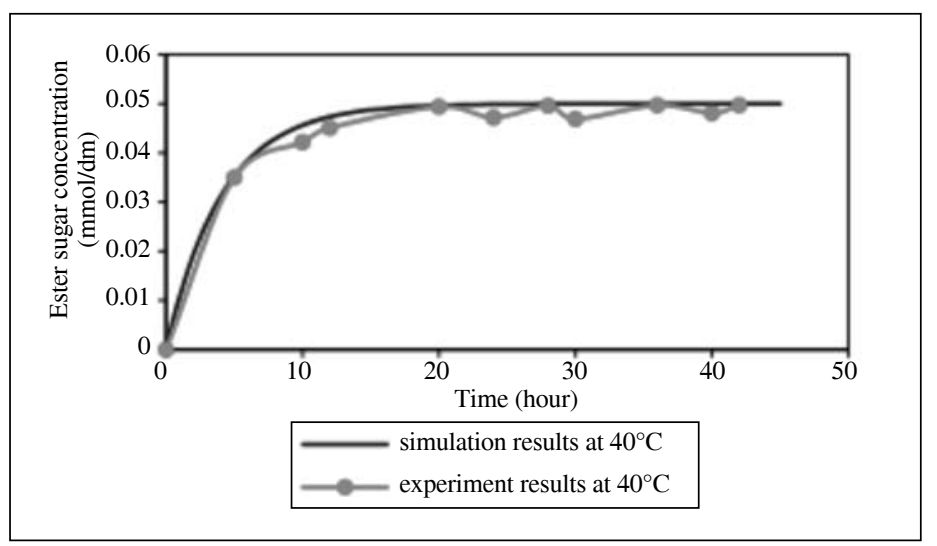

Figure 10: Comparison between simulation and experiment results at $40^{\circ} \mathrm{C}$

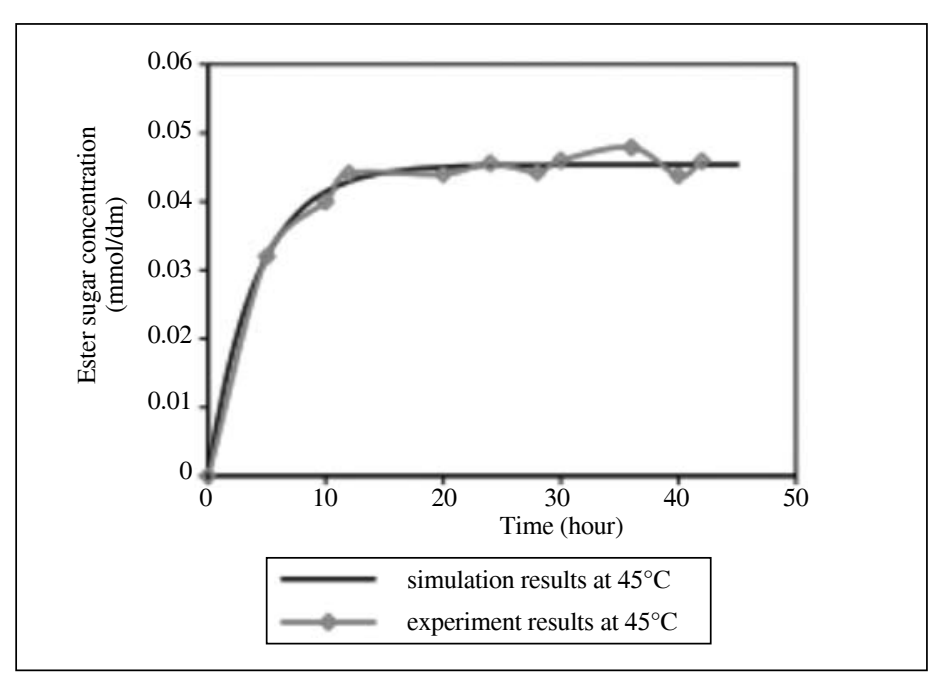

Figure 11: Comparison between simulation and experiment results at $45^{\circ} \mathrm{C}$

Figures 8 to Figure 11, show that for each temperature the profiles of ester sugar ester concentrations were in similar trend between the simulation and experimental results. The different between simulation and experiment value still in the acceptable range, with maximum error percent less than $11 \%$. The reasons simulation results differ from the experimental due to errors occurred in experimental work:

(i) Changes of sugar concentration caused by some of the solvent evaporate out while doing during experiment.

(ii) Fluidisation effect partially achieved because of the air or gas that pumped into was not pumped directly from the bottom part of column but rather ducted to the bottom and then getting out at the bottom of the column.

(iii) Mass lost occurred every time samples were transferred from the rotary evaporator to a beaker to another beaker for analysis.

(iv) Not $100 \%$ isopropyl alcohol can be separated using rotary evaporator.
Based on theory for simulation, there is constraint as below:

(i) The hydrodynamic effects such as diffusion of substrate to enzyme and mass transfer between solid phase and liquid phase were not incorporated in the development of model.

(ii) Product that calculated was based on the balance of diester concentration in the product. Meanwhile, thin layer chromatography method cannot differentiate monoester and diester.

(iii) PFAD consisted of several types of fatty acid, but the type of ester sugar produced was not identified, thus the type of fatty acid involved was uncertain. Kinetic parameter used to run simulation is from experimental data.

\subsection{CONCLUSIONS}

From the study it can be concluded that the optimum temperature for the production of sugar ester was at $40^{\circ} \mathrm{C}$ using the Ping Pong Bi Bi Model. The experimental results deviate slightly from the simulation results with error percentage of less than $11 \%$. The model can be used to predict the production of sugar ester when the concentrations of the reactants are varied.

\subsection{ACKNOWLEDGEMENT}

The research is funded by Fundamental Research Grant Scheme (FRGS) by Ministry of Higher Education, MOHE (UKM-KK-02-FRGS0126-2009) which are duly acknowledge by authors.

\section{NOMENCLATURE}

the activity of enzyme and equal to the enzyme initial mass, Ao

Apparent Rate constant, $\mathrm{K}_{2}{ }_{2}$ and $\mathrm{K}_{3}$,

concentration for sugar, $[G]$

deactivate, $\left(k_{d a}\right)$

enzyme ratio, $(\alpha)$

Initial Palm Oil Fatty Acid Distillate, [Fao]

$\mathrm{K}_{20}$ is inversed to $\mathrm{y}$ interception while $\mathrm{k} 1$ is a graph slope monoester $(M)$ and diester, $(D)$

Malaysian Palm Oil Board, (MPOB)

Palm Oil Fatty Acid Distillate, (PFAD)

thin layer chromatography, (TLC)

Rate constant, $\mathrm{K}_{2}$ and $\mathrm{K}_{3}$,

Refractive Index, $\mathrm{R}_{\mathrm{f}}=\mathrm{L}_{2} / \mathrm{L}_{0}$

Time, $(t)$ 


\section{REFERENCES}

[1] Cauglia, F. and Canepa, P. The Enzymatic Synthesis of Glucosylmyristate as a Reaction Model for General Consideration on "Sugar Esters" Production. Bioresource Technology, Vol. 99, pp : 4065-4072, 2008.

[2] Herawan, T. Preparation of Biodegradable Surfactant from Sugar and Palm Fatty Acid Distillate. Master Thesis, Universiti Kebangsaan Malaysia (in Bahasa Malaysia), 1997.

[3] Ljunger, G. Adlercreutz, P. Mattiasson and B.. Lipase Catalyst Acylation of Glucose. Biotechnol. Lett., Vol.16, No.11, pp: 187-204, 1994.

[4] Villo, L., Kreen, M., Kudryashova, M., Metsala, A., Tamp, S., Lille, O. Pehk, T. and Parve, O. A Chemoenzymatic Synthesis of Desoxy Sugar Esters Involving Stereoselective Acelyation of Hemiacetals Catalyzed by CALB. Journal of Molecular Catalisis B: Enzymatic, Vol.68, pp : 44-51,2011.

[5] Paiva, A.L., Balcao, V.M. and Malcata, F.X.. Kinetics and mechanisms of reactions catalyzed by immobilized lipases. Enzyme and Microbial Technology, Vol.27, pp.187-204, 2000.
[6] Lily, M.D. and Dunhill, P. Immobilized-Enzyme Reactors. Methods in Enzymology., Vol.44, pp: 717-718, 1976.

[7] Missen, R.W., Mims, C.A. and Saville, B.A. Introduction to Chemical Engineering and Kinetics. New York, John Wiley and Sons, 1999.

[8] Khaled, N., Montet, D., Pina, M. and Graille, J. Fructose Oleat Synthesis in Fixed Catalyst Bed Reactor. Biotechnology Letters, Vol.13 No.3, pp. : 167-172, 1991.

[9] Shuler L Michael and Kargi F. Bioprocess Engineering; Basic Concepts. 2nd edition ,New Jersey. Prentice Hall, 2002.

[10] Khaled, N., Montet, D., Farines, M., Pina, M. and Graille, J. Synthese de Mono-Esters de Sucre par Biocatalyse. Oleagineaux, Vol.47, No.4, pp : 181-189, 1992.

[11] Norliza Abd. Rahman, Masitah Hassan, Mohd. Azlan Hussain and Jamaliah Md. Jahim.. Mathematical modeling of fructose production by immobilised glucose isomerase as a function of temperature and $\mathrm{pH}$ variations. African Journal of Biotechnology. Vol.10, No.14, pp. 2766-2779, 2010.

\section{PROFILES}

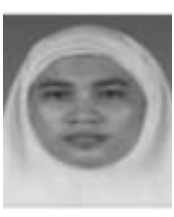

PN. NORLIZA BT. ABDUL RAHMAN is a lecturer in the Department of Chemical and Process Engineering, Faculty of Engineering and Built Environment, Universiti Kebangsaan Malaysia. Her areas of expertise are process control, modelling, Artificial Intelligence Techniques and enzymatic reaction. Currently, she is the coordinator for laboratory courses for 3rd year and Computer Aided Design for 4th year Chemical Engineering programme.

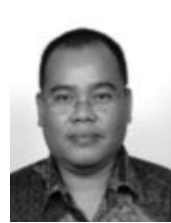

EN. NOORHISHAM TAN KOFLI received his MSc (Biochemical Engineering) in 1993 from the University of Birmingham, U.K. and Postgrad Diploma (Biotechnology) 2002 from Osaka University, Japan. He is now a Senior Lecturer in the Department of Chemical and Process Engineering, Faculty of Engineering and Built Environment, UKM. His research interests include fermentation technology, bioethanol production, lactic acid bacteria and enzyme technology.

MS. SAM YET was a student at the Department of Chemical and Process Engineering, Faculty of Engineering and Built Environment, UKM. She was graduated in 2003 with Biochemical Engineering Degree. Currently, she is working in $\mathrm{UAE}$ as an engineer. 